\title{
Baqueteamento digital como manifestação inicial de neoplasia pulmonar*
}

\author{
Digital clubbing as the initial diagnosis \\ of bronchogenic cancer*
}

\author{
Alex Gonçalves Macedo ${ }^{1}$ \\ Sandra Lopes Mattos e Dinato ${ }^{4}$
}

\author{
Valeria Cristiane Fusari ${ }^{2}$ \\ Ney Romiti
}

José Roberto Paes de Almeida ${ }^{3}$

\begin{abstract}
Resumo: Os autores descrevem caso de baqueteamento digital, o qual possibilitou diagnóstico de carcinoma broncogênico em paciente assintomático. Baseados em levantamento bibliográfico, discutem sua fisiopatologia, associações com alterações sistêmicas e métodos para diagnóstico precoce, enfatizando sua importância, vista a associação do mesmo com várias doenças, incluindo neoplasias pulmonares.

Palavras-chave: carcinoma broncogênico; osteoartropatia hipertrófica secundária.

Summary: The authors describe a case of digital clubbing, which led to a diagnosis of bronchogenic cancer in an asymptomatic patient. Based on a review of the literature, we discuss its physiopathological aspects, associations with systemic conditions and recent methods for early diagnosis of digital clubbing. We emphasize the disease's importance in light of its association with several other diseases, including bronchogenic cancer.

Key words: carcinoma, bronchogenic; osteoarthropathy, secondary hypertrophic.
\end{abstract}

\section{INTRODUÇÃO}

O baqueteamento digital foi descrito há cerca de 2.400 anos, por Hipócrates, ${ }^{1,2}$ como hipocratismo digital associado à doença pulmonar incapacitante, provavelmente enfisema pulmonar. ${ }^{3}$ A partir dessa apresentação, vem sendo descrito associado a várias doenças, como DPOC, cirrose hepática, cardiopatias congênitas cianóticas, neoplasias malignas pulmonares, doenças inflamatórias intestinais, entre outras, podendo ser também de origem congênita. ${ }^{1}$ Caracteriza-se por aumento do diâmetro das falanges distais e alterações das unhas. É classificado em cinco estágios: Grau I - aumento e flutuação do leito ungueal; Grau

\section{INTRODUCTION}

Digital clubbing was first described some 2,400 years ago by Hippocrates ${ }^{1,2}$ as digital hippocratism. It was associated with a disabling lung disease, most likely pulmonary emphysema. ${ }^{3}$ Based on this presentation, the disease has been associated with several other of similar type, including chronic bronchitis, hepatic cirrhosis, congenital cyanotic cardiopathy, malignant lung cancer, inflammatory intestinal diseases, among others that may also be of congenital origin.' It is characterized by an increase in diameter of the distal phalanges and alterations to the fingernails. It is classified into five phases: Phase I - increase and fluc-

\footnotetext{
Recebido em 18.12.2001. / Received on December 18, 2001.

Aprovado pelo Conselho Consultivo e aceito para publicação em 10.09.2003. / Approved by the Consultive Council and accepted for publication on September 10, 2003.

* Trabalho realizado no Serviço de Dermatologia da Unilus. / Work done at Dermatology Service, Unilus.

${ }^{1}$ Mestre em Pneumologia, Escola Paulista de Medicina, Unifesp; Prof. Assistente do Departamento de Clínica Médica da Disciplina de Pneumologia, Unilus / Master's Degree in Pneumology, Escola Paulista de Medicina, Unifesp; Assistant Professor, Clinical Medicine Section, Pneumology Department, Unilus.

${ }^{2}$ Médica Dermatologista sócia aspirante SBD Hospital Guilherme Álvaro, Unilus. / MD, Dermatology of Guilherme Alvaro Hospital, Unilus.

${ }^{3}$ Prof. Especialista em Dermatologia. Mestrando da Unilus / Professor specialized in Dermatology, Master's Degree candidate, Unilus.

${ }^{4}$ Prof. Dra. em Dermatologia FMUSP. Chefe do Departamento de Clínica Médica da Unilus / Professor, Ph.D. in Dermatology, FMUSP. Head of the Clinical Medicine Department, Unilus

${ }^{5}$ Prof. Livre-Docente em Dermatologia. Responsável pela disciplina de Dermatologia na Unilus / Professor, lecturer in Dermatology, Head of the Dermatology Service, Unilus 
II - perda do ângulo natural de $15^{\circ}$ entre a unha e a cutícula; Grau III - acentuação da convexidade do leito ungueal; Grau IV - aparência de baqueta da extremidade digital; e Grau V - aumento da extremidade com espessamento da falange distal e estriações longitudinais na unha. ${ }^{1,2}$ Em relação ao carcinoma broncogênico, os ossos geralmente não estão alterados no baqueteamento digital, salvo quando da presença da osteoartropatia hipertrófica pulmonar, a mais comum das síndromes paraneoplásicas nos tumores de pulmão; ${ }^{3,4}$ porém, é de descrição rara como manifestação inicial da referida neoplasia.

O objetivo deste estudo é ilustrar a ocorrência de baqueteamento digital como queixa principal, a qual levou ao diagnóstico de neoplasia maligna pulmonar em um paciente adulto do sexo masculino.

\section{RELATO DE CASO}

Paciente do sexo masculino, 42 anos, casado, comerciante, procurou serviço médico com quadro de aumento de volume dos dedos notado pela esposa do paciente e posteriormente pelo mesmo, há cerca de dois meses. Refere também modificação na forma das unhas modificaram sua forma nesse período. Paciente nega qualquer outro sintoma ou sinal, incluindo tosse, emagrecimento e escarros hemoptóicos.

Ao exame físico, BEG e baqueteamento digital grau V nas mãos (Figura 1).

Hábitos sociais: etilista social de duas cervejas por final de semana. Tabagista de 40 anos/maço (equivale a dois maços por dia durante 20 anos).

Antecedentes familiares: pai falecido de câncer de pulmão e irmão operado de neoplasia de laringe.

- Foram solicitados exames iniciais que demonstraram:

- hemograma, bioquímica, ECG, lipidograma e urina I: normais;

- TGO, TGP, bilerrubinas totais e Fr., fosfatase alcalina e GamaGT: normais;

- Rx de mãos: normais;

- Rx Tórax: opacificação em região para-hilar direita espiculada, com características neoplásicas (Figura 2).

- Com essas alterações, o paciente foi encaminhado da Dermatologia para a Pneumologia, onde prosseguiu na investigação diagnóstica, sendo solicitado os seguintes exames:

- Tomografia computadorizada de tórax: massa de características neoplásicas em lobo inferior direito, sem

Figura 1: Mão direira com dedos em baquetas de tambor. tuation of the ungual bed; Phase II - loss of the natural $15^{\circ}$ angle between the nail and cuticle; Phase III - heightened convexity of the ungual bed; Phase IV - clubbed appearance of the digital extremity; Phase $V$ - increase of the extremity, with thickening of the distal phalange and longitudinal striations on the fingernail. ${ }^{1,2}$ In relation to bronchogenic cancer, the bones are not usually altered in digital clubbing, except when pulmonary hypertrophic osteoarthropathy is present, which is the most common of paraneoplasic syndromes in lung tumors. ${ }^{3,4}$ However, it seldom appears as the initial manifestation of the aforementioned neoplasia.

The aim of this study is to illustrate the occurrence of digital clubbing as a patient's main complaint, which subsequently led to a diagnosis of malignant pulmonary neoplasia in an adult, male patient.

\section{CASE REPORT}

A 42-year-old married male patient shopkeeper sought medical assistance with a condition of increased finger volume which was noticed by the patient's wife, and later by himself, about two months ago. He also referred to changes in the shape of his fingernails during this period. The patient denied having had other symptoms or signs, including coughing, weight loss and hemoptoic expectoration.

The physical examination showed BEG and Phase $V$ digital clubbing in the hands (Figure 1).

Patient's social habits: social consumer of two beers per weekend. Smoker, 40 years/pack (equivalent to two packs per day for 20 years).

Family background: father died of lung cancer and brother operated for neoplasia of the larynx.

- The following tests were solicited at first and showed:

- Hemogram, biochemistry, ECG, lipidogram and urine I: normal

- TGO, TGP, total bilirubins and Fr, alkaline phosphate and GammaGT: normal;

- Hand x-ray: normal;

- Thorax x-ray: opacification in the right spiculated para-hilar region, with neoplasic characteristics (Figure 2);

- With these alter-

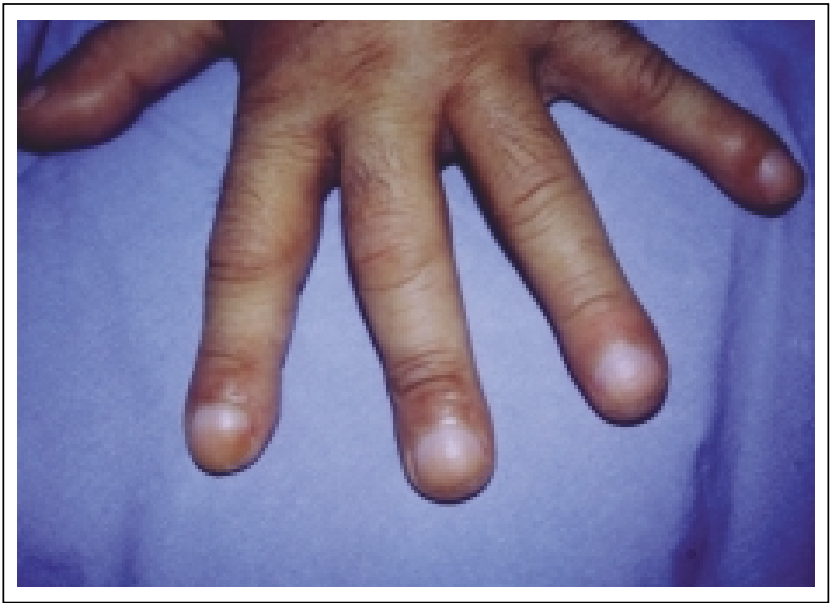
ations, the patient was then sent from Dermatology to Pneumology, where the diagnostic investigation proceeded. The following tests were solicited:

- Computerized tomography of the thorax: on the right inferior lobe there was a mass with neoplasic char-

Figure 1: Right hand with drumstick fingers. 
presença de gânglios em mediastino. (Figura 3);

- Broncoscopia: não apresentava lesões endobrônquicas. Lavado brônquico, escovado e biópsia transbrônquica em lobo inferior direito foram negativos para células neoplásicas. O procedimento foi repetido duas vezes, sem diagnóstico definitivo.

Em virtude das características clínicas e radiológicas do paciente, optou-se por videotoracoscopia com biópsia por congelação, que demonstrou ser patologia polimitótica. No mesmo procedimento foi realizada toracotomia com lobectomia inferior direita. O estudo anatomopatológico da peça evidenciou carcinoma indiferenciado de grandes células.

Evolução: paciente permaneceu estável no pós-operatório. Com um mês apresentou dor na região costal posterior, evoluindo com paraplegia. Os exames demonstraram metástases ósseas em coluna e costelas. Apesar de cirurgia descompressiva e radioterapia, a doença foi progressiva com metástases hepáticas, evoluindo para óbito em dois meses.

\section{DISCUSSÃO}

Durante anos, as síndromes paraneoplásicas têm sido estudadas quanto a sua fisiopatologia, incidência e relação com as várias neoplasias, porém com pouco avanço em sua patogênese, a qual permanece desconhecida. Acredita-se que ocorra vasodilatação das veias das pontas dos dedos, aumentando a pressão hidrostática nos capilares que, por sua vez, promove movimentação do fluído para dentro do interstício, resultando no aumento das partes moles. ${ }^{5,6}$

É relatada associação com aumento de ACTH, fator ativador das plaquetas, além de outros mediadores e síndrome de Cushing, ${ }^{7,8}$ Nas últimas publicações descreveu-se a presença de um hormônio de crescimento hepatocitário em pacientes com baqueteamento associado a cirrose hepática, acteristics, though no presence of ganglions mediastinum (Figure 3);

- Bronchoscopy: did not show any endobronchial lesions. Bronchial washing, brushing and transbronchial biopsy in the right lower lobe were negative for neoplasic cells. The procedure was repeated twice, with no definitive diagnosis.

In virtue of the patient's clinical and radiological characteristics, videothorascopy with a biopsy for freezing was the method adopted, and showed a polymitotic pathology. Thoracotomy was performed with a lower right lobectomy during the same procedure. The anatomopathologic study of the piece displayed large cell undifferentiated carcinoma.

Progression: the patient's condition remained stable during the post-operatory phase. One month later, he showed signs of pain in the posterior costal region, which progressed to paraplegia. The tests showed bone metastases in the spinal column and ribs. Despite decompressive surgery and radiotherapy, the disease progressed into hepatic metastases, which led to the patient's death in two months.

\section{DISCUSSION}

For years, paraneoplasic syndromes have been studied in an attempt to understand their physiopathology, incidence and relation with various neoplasias. Yet there have been few advances in their pathogenesis, which is still not known. Vasodilation of the veins at the fingertips is believed to occur, which increases the hydrostatic pressure in the capillaries. This in turn promotes movement of fluid inside of the interstice, and results in swelling of the soft-tissue parts. ${ }^{5,6}$

An association with paraneoplasia has been reported with increased amounts of ACTH, i.e. a platelet-activating factor as well as for a variety of other mediators, and with Cushing's syndrome. ${ }^{7,8}$ In the latest publications, the presence of a hepatocytic-growth hormone has been described in patients with clubbing in association with

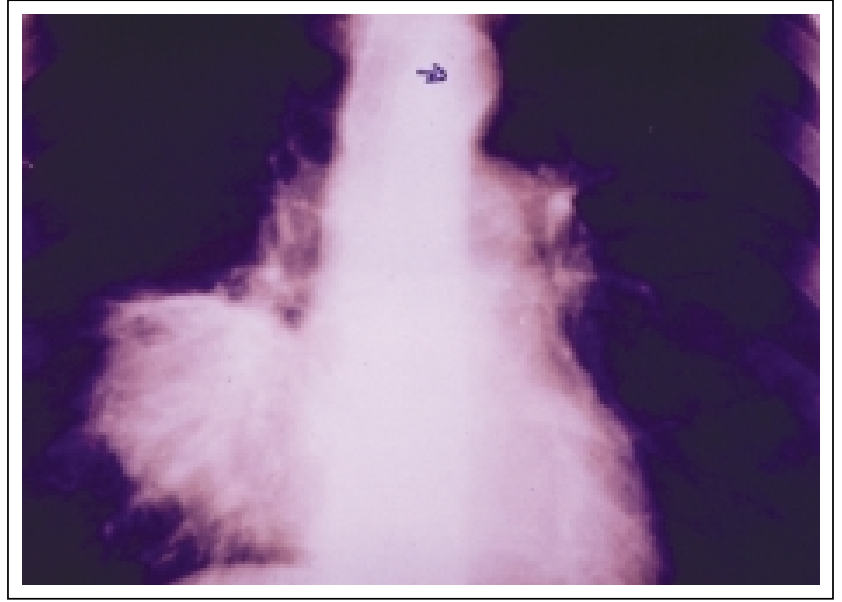

Figura 2: RX de tórax em PA com massa paracardíaca direita. Figure 2: X-ray of thorax in AP with a mass on the right paracardiac region.

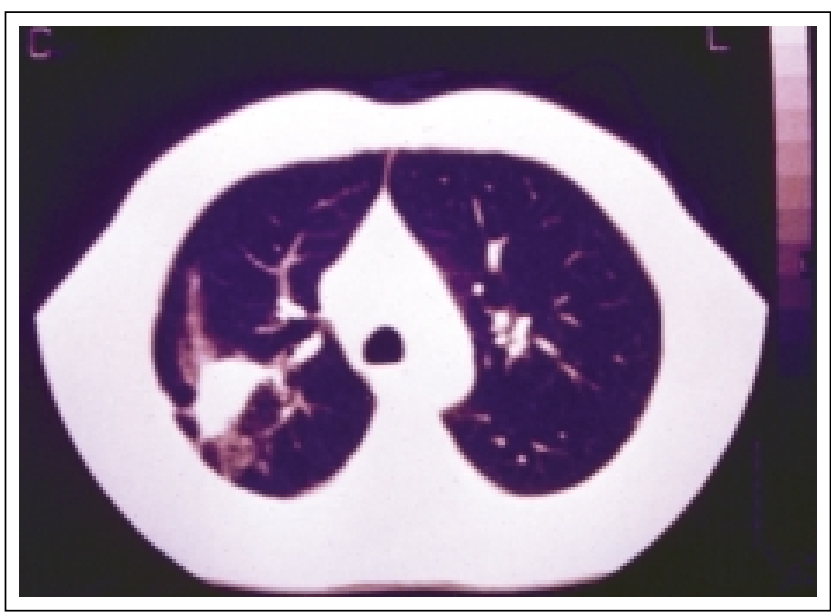

Figura 3: TC de tórax com massa espiculada em lobo inferior direito / Figure 3: CT of thorax with spiculated mass on right lower lobe. 
hepatocarcinoma e adenocarcinoma pulmonar. ${ }^{9,10}$

O diagnóstico tem sofrido modificações durante os últimos anos, com base nas tentativas de uma classificação clínica que o defina. Frente à suspeita clínica de baqueteamento, pode-se utilizar a avaliação da relação da profundidade das falanges distais e das articulações interfalangeanas e a relação dessas duas profundidades com relação normal menor do que um. Na prática mede-se a distância das extremidades das falanges distais e das articulações interfalangeanas no sentido anteroposterior e faz-se esta relação (medida óssea/medida articular sendo essa $<1$ como normal) $)^{3,11-14}$ (Figura 4 A). Essa escala clínica é útil nas fases iniciais da doença, pois na fase avançada o diagnóstico pelo exame clinico é relativamente fácil, como no caso deste paciente, que apresentava grau V. Além da avaliação clínica podem ser utilizados a capilaroscopia, o Rx. simples de dedos, a tomografia computadorizada simples e com emissão de pósitrons, que podem definir padrões da doença, porém tem utilidade clínica irrelevante. ${ }^{11,12,15}$ Outra medida de avaliação da presença de baqueteamento é o diâmetro das falanges, sem graduação, sendo o normal a distância A - B sempre maior do que a distância C - D (Figura 4 B).

A associação das alterações digitais ocorre em cerca de $12 \%$ das neoplasias pulmonares, sendo mais comum em mulheres do que em homens, contrariamente ao caso aqui apresentado.

É a síndrome paraneoplásica mais comum dos tumores broncogênicos. Pode estar associada a outras síndromes, sendo a associacão de mais de duas paraneoplasias extremamente rara. Dessas, a síndrome inapropriada de hormônio antidiurético, síndrome de Cushing e síndrome de EatonLambert são as mais comuns.

Entre os tipos histológicos, o adenocarcinoma é o mais freqüentemente associado, sendo seguido pelo carcinoma indiferenciado de grandes células (que foi encontrado no paciente aqui apresentado), epidermóide e o de pequenas células. ${ }^{1,16,17,18}$

A apresentação de baqueteamento digital como manifestação inicial de neoplasia broncogênica é rara, pois normalmente sua formação parece depender da produção

Figura 4 A: Relação da profundidade das falanges distais e interfalangeanas. Figura 4B: Normal: ângulo menor 180

formado entre 0 dorso da falange distal(E) e média (A) Distância entre $C-D<$ que $A-B$

Clubbing: ângulo maior 180 formado entre o dorso da falange distal $(E)$ e média $(A)$ Distância entre $C-D>A-B$. hepatic cirrhosis, hepatocarcinoma and pulmonary adenocarcinoma. ${ }^{9,10}$

The diagnosis has undergone modifications during recent years following attempts of creating a clinical classification that would define it. When suspected clinical suspicion, one may choose to proceed to an assessment of the ratio of depth between the distal phalanges and interdigital joints, and the ratio of these two depths to a normal lessthan-one ratio. In practice, one measures the distance between the distal phalange extremities and interphalangeal joints from front to back, so as to determine the ratio (bone measurement vs. joint measurement $<1$, normal) (Figure 4 A)., ${ }^{3,1-14}$ This clinical scale is useful in the initial phases of the disease, but in the advanced phase the diagnosis by clinical examination is relatively easy, as in this patient's case who presented with Phase V. In addition to the clinical assesment, one may use capillaroscopy, simple X-ray of the fingers, simple computerized tomography or with positron emission. These might define disease patterns or have no clinical utility at all. ${ }^{1,12,15}$ Another means of assessing the presence of clubbing is by measuring finger diameter, with no graduated scales. The normal distance between $A-B$ is always greater than the distance between $C$ - $D$ (Figure $4 B$ ).

The association with digital alterations occurs in roughly $12 \%$ of pulmonary neoplasias. It is more common in women than men, which contrasts with the case presented in this paper.

It is the most common paraneoplastic syndrome of bronchogenic tumors. It may be associated with other syndromes. The association of more than two paraneoplasias is extremely rare. In the latter, inappropriate antidiuretic hormone syndrome, Cushing's syndrome and Eaton-Lambert's syndrome are the most common.

Among the histological types, adenocarcinoma is most frequently associated with it, followed by undifferentiated largecell carcinoma (which was found in the patient presented herein), epidermoid carcinoma and small-cell carcinoma. $^{1,16,17,18}$

The appearance of digital clubbing with an initial manifestation of bronchogenic neoplasia is rare,

Figure 4 A: Ratio of the depth of the distal phalanges and inter-phalanges. Figure 4B: Normal: angle below 180 formed by the dorsal (E) and medial (A) aspects of the distal phalange. Distance between C-D < A-B. Clubbing: angular above 180 formed by the dorsal (E) and medial (A) aspects of the distal phalange. Distance between C-D > A-B. 
de algumas substâncias pelo próprio tumor. $\mathrm{O}$ sintoma mais precoce de tumor de pulmão é o emagrecimento, o que curiosamente não ocorreu nesse paciente, que pode ser acompanhado de tosse, porém, pouco valorizada pelo paciente por relacioná-la ao tabagismo.

Não foi encontrada na literatura a descrição de baqueteamento digital como motivo de consulta inicial, na qual o diagnóstico final resultou em neoplasia pulmonar. Os autores acreditam que essa deva acontecer com pouca freqüência, visto que mesmo a presença do próprio baqueteamento como síndrome paraneoplásica, apesar de a mais freqüente, demonstra-se de baixa incidência. Acreditam também que a utilização de métodos randomizados para pesquisa diagnóstica do baqueteamento digital na fase inicial poderia aumentar essa incidência, particularmente em pacientes com antecedentes familiais relevantes.

\section{CONCLUSÃO}

Após revisão bibliográfica estimulada pela presença de caso inusitado, os autores puderam observar que a presença do baqueteamento digital como manifestação inicial de neoplasia pulmonar é extremamente rara. Sua fisiopatologia continua indefinida e seu diagnóstico ainda suscitam dúvidas, sendo propostos alguns métodos que tentam diminuir o caráter subjetivo do diagnóstico clínico, particularmente nas fases iniciais. Acreditam que a pesquisa ativa em pacientes de potencial risco para o desenvolvimento de neoplasias pulmonares possa evidenciar maior incidência dessa paraneoplasia até como manifestação inicial do quadro.

Ressaltam a importância do exame dermatológico na elucidação de doenças internas.

\section{REFERÊNCIAS / REFERENCES}

1. Sridhar KS, Lobo CF, Altman RD. Digital Clubbing and lung cancer. Chest 1998;114(6):1535-1537

2. Kelly WN, Harris ED, Ruddy S et al. Textbook of Rheumatology 5th. Ed. Philadelphia: W.B. suders Company, 1997; 1514-1520

3. Baughman RP, Gunter KL, Bushusbaum JA, Lower EE. Prevalence of digital clubbing in bronchogenic carcinoma by a new digital index. Clinical and Experimental Rheumatology 1998;16:21-26

4. Monsieur I, Meysman M, Noppen M, Vincken W. Nomsmall-cell lung cancer with multiple paraneoplastic syndromes. Eur Respir dis 1995; 8:1231-1234

5. Bigler FC. The morphology of clubbing Am J. Pathol 1958; 34:237-50

6. Racoceanu SN, Mendlowitzn, Suck AF, Wolf RL, Nafthi NE. Digital capillary blood flow in clubbing. Ann Intern Med 1971;75:933-5 because its formation often seems to depend on some substances being produced by the tumor itself. The earliest symptom of lung tumor is weight loss, which oddly did not occur with this patient. Weight loss may be accompanied by coughing, though the patient here did not seem duly concerned about his coughing as he associated it with his smoking habit.

There was no description found in the literature of digital clubbing as being the first motive for medical consultation in which the final diagnosis was pulmonary neoplasia. The authors believe this to occur quite seldom, given that even the presence of clubbing itself as a paraneoplastic syndrome, in spite of its greater frequency, shows low incidence. It is also believed that the use of randomized methods for research on a diagnosis of digital clubbing in the initial phase might increase its incidence, especially in patients with a relevant family history.

\section{CONCLUSION}

Upon reviewing the bibliography as prompted by the presence of this unusual case, the authors could observe that the presence of digital clubbing as the initial manifestation of pulmonary neoplasia is extremely rare. Its physiopathology remains undefined and its diagnosis still raises several doubts. Some methods tending to reduce the subjective aspect of clinical diagnoses, especially in the early phase, have been proposed in this paper. The authors believe that active research on patients with a potential risk for developing pulmonary neoplasias might reveal a greater incidence of this paraneoplasia as the condition's initial manifestation. Moreover, it is worth emphasizing the importance of dermatological examinations for elucidating internal diseases.

7. Dickinson CJ. The aetiology of clubbing and hypertrophic osteoarthropathy. [Review] Eur J Clin Invest 1993;23:330-8

8. Silveri F, Carlino G, Cervini C. The endothelium platelet unit in hypertrofic osteoartrhopathy. Clin Exp Rheumatol 1992; (suppl.7): 61-6

9. Hojo S, Fujita J, Yamadori I et al. "Hepatocyte growth factor and digital clubbing Intem Med 1997;199736:44-46 10. Yacoub MH. Relation between histology of brochial carcinoma and hyperthrofic pulmonary osteoarthropaty. Thorax 1965; 20:537-539

11. Fara EF, Baughman RP. A study of capillary morphology in the digits of patients With acquired clubbing. Am Ver Respir Dis 1989; 140: 1063-6

12. Mellins RB, Fishman AP. Digital casts for the study of clubbing of the fingers. Circulation 1966; 33: 145 
13. Waring WW, Wilkinson RW, Wieb RA, Faol BC, Hilman BC. Quantitation of digital clubbing children. Measurements of cast of the index fingers. Am ver Resp Dis 1971; 104:166-74

14. SLY RM, Chazanshahi S, Buranakul B et al. Objective assessment for digital clubbing in Cancasian, Negro, and Oriental subjects. Chest 1973; 64:687-9

15. Ward RW, Chin R JR, Keyes JW Jr, Haponik EF. Digital clubbing. Demonstration With positron emission tomography. Chest 1995; 107:1172-3.

16. Talley NJ, O Connon J. Clinical Examination. 3rd ed. Australia: MacLennan \& Petty Limited, 1996;34

17. Semple T, Mc Cluskie RA. Generalized Hypertrophic
Osteoarthropathy in association With bronchial carcinonma: a review, based on 24 cases. Br Med J 1955;1:754-759 18. Hope RA, Longmore JM, Hodgetts TJ et al. Oxford Handbook of Clinical Medicine 3rd. Ed. New Yorkk. Oxford University Press Inc., 1996; 42.

ENDEREÇO PARA CORRESPONDÊNCIA: / MAILING ADDRESS:

Valéria Cristiane Fusari

Rua Siqueira Campos 634/122

11045-200 Santos SP 